\author{
REVIEW OF EUROPEAN AND COMPARATIVE LAW \\ VOLUME XLII \\ YEAR 2020, ISSUE 3, pp. 169-191 \\ DOI: https://doi.org/10.31743/recl.8672
}

\title{
BUSINESS IN THE U.S. DEMOCRACY
}

\author{
Emeric Solymossy*
}

\begin{abstract}
This paper discusses a model of business in a "democracy" by identifying the three underlying concepts; the individual, the collective (society), and the government (system and mechanics). Furthermore, each of these elements is also a multi-factor construct. The foundations and development of the United States is discussed. The exploration, discovery and development of any new country require risk taking and innovative behavior, which was instrumental in the creation of heroes and myths, which shaped much of the culture. From this background, some of the principle characteristics of the entrepreneur are explored and correlated to some generally accepted measures of national culture. The concepts are developed; their inter-relationships and the resulting dynamics are presented. The foundation(s) and uniqueness of the U.S. form of democracy is explored as a government typology. Data is presented exhibiting the variability of business confidence, and a conclusion is reached that the attitudes and policies of the government have a greater impact on business formation and success than the form of government.
\end{abstract}

Keywords: business in democracy, model of business, the United States

* Ph.D., Emeric Solymossy, Professor Emeritus, Western Illinois University, College of Business and Technology, e-mail: eSolymossy@gmail.com. 


\section{INTRODUCTION}

The U.S. is currently experiencing economic growth while many other economies are stagnant or declining. A longitudinal study by $\operatorname{Roser}^{1}$ notes changes in GDP per capita using four points in time: 1950, 1970, 1990, and 2019. Two phrases from the paper are important:

1. "What economic growth makes possible is that everyone can become better off, even when the number of people that need to be served by the economy increases. 2 An almost 3-fold increase of the population multiplied by a 4.4-fold increase in average prosperity means that the global economy has grown 13-fold since 1950." 2

2. "Failure to grow the economy and to provide the goods and services that they need is one of the largest failures in recent decades. It means that populations in these places are now much worse off than the rest of the world - they are less healthy and die sooner, education is poorer, and many suffer from malnutrition."

The question of what facilitates business implementation and growth generates a lot of attention. The definitions for business and government are explained, and the paper develops the concepts, explores the elements and their frameworks and the interrelationships of the three essential elements (the individual, society, and democracy (or government) that influence business formation and endurance.

\section{BUSINESS}

"Business" is often used to imply entrepreneurial enterprises to promote economic development. However, it is also used to characterize existing, small ventures focusing on continued operation rather than growth as the principle objective. (e.g. restaurants, small grocers, tradespeople).

1 Max Roser, "Which Countries Achieved Economic Growth? And Why Does It Matter?” in Our World in Data, 2019, https://ourworldindata.org/economic-growth-since-1950.

2 The population increase wasn't quite 3 -fold (but 7.43/2.53=2.937-fold) and the prosperity increase was more than 4.4 -fold (but $14,574 / 3300=4.416$-fold) so that the world economy grew 2.937*4.416=12.97-fold between 1950 and 2016 . 
It is also often used to characterize larger, established businesses (e.g. Solaris Bus and Coach, CD Projekt, Lidl Poska), and or global enterprises (e.g. Boing, Airbus, PKO Bank Polski, PGE). It is sometimes applied to industries (such as manufacturing, technology, service, utilities, consumer goods) None of the foregoing applications would be applicable as they are overly restrictive. Therefore, business is hereinafter defined as:

An individual or individuals organized as an economic enterprise, engaged in commercial, industrial, or professional activities where goods and services are exchanged for other enterprise's goods, activities, or monies.

This definition is intentionally inclusive of organized economic enterprises without regard to size, growth, ownership, industry, or market. It should also be noted that this definition implies that the production or transactions involve value creation. The limitation of value creation is important, especially when joining the terms business and government.

All enterprise, including large, global organizations had their beginnings as entrepreneurial ventures. As such, there are three very important aspects to be recognized: 1) person(s) with necessary competence, 2) risk, and 3) opportunity (to capture a market). Hernando DeSoto's book ${ }^{3}$ identified private property as a fundamental requirement for business to succeed (and impact the economy). This requires an economic and legal framework. The dynamics of people, opportunity and risk imply a reliance on this framework. This is a function of government, which has influences beyond this framework. There are 20 types of government, ranging from Authoritarian to Totalitarian (alphabetically), including eight forms of democracy.

\section{DEMOCRACY}

Democracy, exists in multiple forms; Pure (direct) Democracy, Representative, Presidential, Parliamentary, Authoritarian, Participatory, Islamic

3 Hernando DeSoto, The Mystery of Capital: Why Capitalism Triumphs in the West and Fails Everywhere Else, Basic Books, 2000. 
and Social ${ }^{4}$. For the purposes of this paper, this discussion focuses on the two most popular forms of democracy; Direct Democracy and Representative Democracy. Jean-Jacques Rosseau wrote extensively on the concept of social contract ${ }^{5}$ (originally published as 1762), arguing that only the people have the sovereign, all power right to empower legislation, with John Stuart Mill ${ }^{6}$ further arguing the freedom of the individual, and the merits of economic democracy and opportunity.

Representative democracies (such as in the U.S., the U.K., Germany, South Africa, Brazil, India, Japan, France, Turkey, Tanzania and many others) are frequently called a Republic. For the purposes of this paper, the differences between a representative democracy and a republic are insignificant. The terms have similar definitions in the Merriam-Webster Dictionary, Dictionary.com, and H.G. Bohn's classic work: The Standard Library Cyclopedia of Political, Constitutional, Statistical and Forensic Knowledge ${ }^{7}$.

In a Direct (pure) Democracy, the people, by majority, decide on policy initiatives (rule of the majority). In a Representative Democracy, people select representatives, who in turn, decide policy initiatives. A Republic, on the other hand, is a term that can be applied to any form of government in which the head of state is not a hereditary monarch, or a tyrannical regime $^{8}$. The term "republic" stems from the Latin "res publica," or "public affair," or not the private concern or property of the rulers.

The United States is a constitutional republic. In this form of government, control is primarily based upon a constitution (law), wherein the people do not control the law. Second, it establishes and protects the independence and sovereignty of each person (male or female) of competent age and capacity. Laws can be changed, however such change can only be effected by a higher source than the government. In the U.S., this requires

4 https://www.scienceabc.com/social-science/different-types-democracy-direct-representative-presidential-parliamentary.html.

5 Jean-Jacques Rosseau, On the Social Contract; or, Principles of Political Rights (Published by Marc Michel, Rev., Amsterdam,1762).

6 Dennis Thompson, John Stuart Mill and Representative Government. Princeton University Press, 1976.

7 Henry George Bohn, The Standard Library Cyclopedia of Political, Constitutional, Statistical and Forensic Knowledge. 4 volumes, London 1849.

8 Encyclopedia Britannica. 
a two-thirds majority vote in both the House of Representatives and the Senate followed by ratification by two-thirds of the state legislatures. (27 of the 27 amendments to the U.S. constitution were approved in this manner), or through a constitutional convention called for by two-thirds of the state legislatures. No Amendments have been approved this way.

The U.S. is young nation, with a storied history that displays more than a unique constitution and governmental form. From inception, it embodied a frontier spirit. People left the security of their city to pursue opportunities in an unsettled and frequently hostile land. This demanded courage, ingenuity and perseverance; it fostered a personality and culture that was individualistic and resistant to the restrictions or control imposed by a community or government. It favored flexibility over rigidities. Cultures create and reinforce stories and myths. The expansion of the country is romanticized by heroes that are well known to youth such as Davy Crocket, Buffalo Bill, Daniel Book, "Kit" Carson, and Lewis and Clark. The cowboy is immortalized, and the world knows of John Wayne. Less well known, but important for their contributions are the farmers who followed the frontiersmen (and women), which established boundaries and initiated the beginnings of civilization and created an environment of industrialization and innovation. Frederick Jackson Turner (writing his thesis in 1892) elevated the linkage between the frontier and the development of U.S. culture. Turner concluded "to the frontier the American intellect owes its striking characteristics. This is in contrast to the rigidity evidenced in many countries and cultures.

Randall Holcombe argued that the founders (authors of the U.S. Constitution) had no intention of creating a democracy where government is guided by popular opinion ${ }^{9,10}$. Holcombe argues that the main purpose of the constitution is to protect the rights of the individual and to limit the size and control of the government. Pure Democracy, on the other hand, requires decisions affecting all are made according the will of the simple

9 Randall Holcombe, Liberty in Peril, Democracy and Power in American History, Independ Institute19, 2019.

10 George Friedman, "The Founding Fathers Never Intended to Create A Direct Democracy," (originally written 2016, updated 2017): Huff Post, U.S. Edition, accessed at: https://www.huffpost.com/entry/the-founding-fathers-never-meant-to-create_b_13051196 
majority. The founders feared governmental persons being under direct influence of individuals or groups driven by self-interest. Society's norms, values, and interests change, often drastically. Shifting cultural and social interests can cause fundamental and enduring changes in governmental laws and regulations. While this is still possible in a Representative Republic, it is less likely.

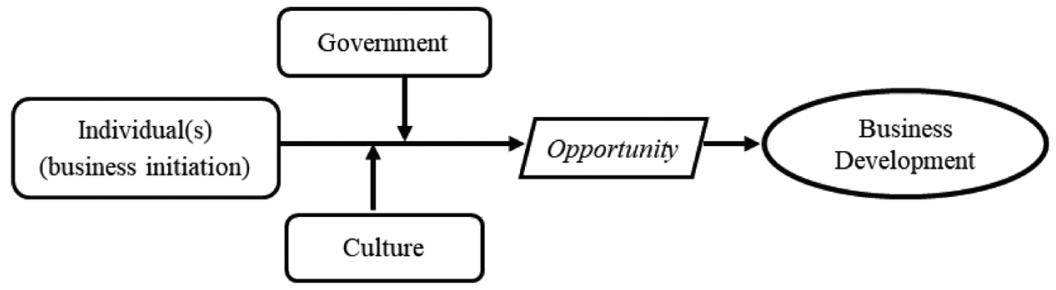

Figure 1: Author's own model diagram

The dependent variable, (the object of interest), is business development. This incorporates business starts, business growth, and subsequent economic growth and distribution of wealth. This outcome can be measured in a variety of mechanisms: business starts, employment growth, or overall economic growth demonstrated by per capita GDP. The norms, values, and perspectives pertaining to business and the culture are moderating variables, impacting the strength of the relationship between the individual and business. Opportunity is a mediating variable since the presence of opportunity allows business, whereas the absence of opportunity prevents business formation.

\section{THE INDIVIDUAL FACTOR}

All business ventures have a starting point; generally instigated by one, or a few individuals working together. The independent variable, there- 
fore, is the individual(s) who initiate a business enterprise or push it to a higher level (for example, Apple Computers and Federal Express.)

Apple was begun by Steve Jobs and Steve Wozniak in 1976 in a garage. Initially, as a member of a computer hobbyist group looking at the MITS' (company, not the Massachusetts Institute of Technology) Altair (basically a box of lights and circuit boards), Steve Wozniak was motivated by a desire to show the capability of an individual (versus a company). He built a computer with a typewriter style keyboard and the ability to connect to a TV. From this innovative point, Steve Jobs pushed it through further (continual) innovation (involving financial, psychological, and social risk). Apple Computers is currently one of the largest economic enterprises in the world.

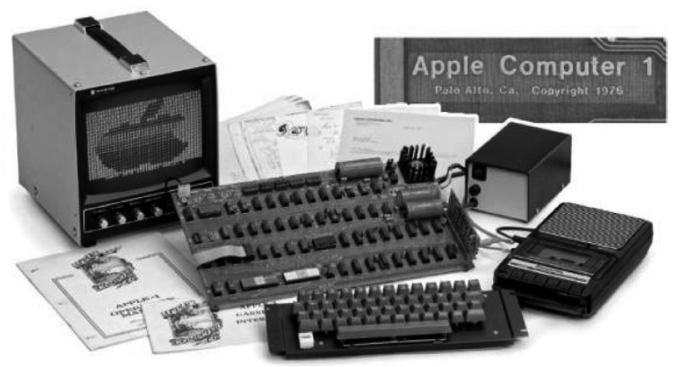

First series of the Apple 1 computer, Built in 1976 (source: Apple.com)

In 1965, while a Yale undergraduate, Fred Smith submitted a paper outlining a system for urgent, time-sensitive material shipment using a centralized hub distribution system. His instructor was not impressed; finding the concept "interesting, but not feasible," and graded it as "average" 11 . Six years later, Fred Smith initiated his original business concept. The first night of continuous operations occurred in 1973; today, Federal Express is a successful global enterprise.

11 Contrary to popular stories, the professor, Challis A. Hall, (Economics 43A) did not "fail" the paper. 
Both of these (virtually ALL business starts) demonstrate three truths that are not often exposed as fundamental. The first is the drive and competence of the initiator (the motivation may be psychological or economic). Second, both demonstrate a significant amount of risk (that prevent others from proceeding), and thirdly, and closely related to risk and competence, is recognizing an opportunity that others either do not see, or deem to be unlikely or "bad". At the time Steve Jobs and Steve Wozniak started Apple, experts questioned the viability of personal computers.

Scholars cite from 5 (Investopedia) to 35characteristics of entrepreneurs $^{12}$ - those individuals who take the risks to pursue their ideas to satisfy an opportunity. Embedded within the concept of competence are the technical and professional skills, the motivation, and the perseverance of the individual(s). Therefore, we can model the individual(s) as the dependent variable, and three (or more) independent variables that contribute to the competence of the individual(s).



Figure 2: Author's own model diagram

It should be noted that each of the three independent variables are interactive, depending upon and influencing each of the other. For instance, a level of technical competency may reduce the perceived level of risk, however, weaknesses in business, marketing, or financial competency might increase the risk, or minimize the likelihood of pursuing the opportunity. Current findings reflected in the 2019 Global Entrepreneurship

12 Tim Berry, “35 Common Characteristic of Successful Entrepreneurs," Bplans, on Palo Alto Software, (undated), https://articles.bplans.com/35-common-characteristics-of-successful-entrepreneurs/. 
Monitor (GEM) indicate that 14\% of working age Americans are starting or running their own business. Even in an entrepreneurial country and culture, the vast majority lack the motivation, competence, and willingness to assume risks. The exception for this is the "survival" motivation. The highest rate of entrepreneurial activity is in Angola, an extremely low-income economy. Most people don't see the opportunity until someone develops it (think Amazon, Facebook, or Starbuck's). How often has one heard, "Gee, I had thought of it, I could have done that!"

\section{THE CULTURAL/SOCIAL FACTOR}

Persons do not develop their personalities in isolation. Psychologists and sociologists maintain that culture influences the way people learn, live, and behave. The culture one is raised in is not the sole determinant of a person's personality. If so, all individuals raised within the same culture would share common personality traits. Culture influences individuals; it moderates (not creates) personality characteristics. Three aspects of culture have varying degrees of influence upon persons pertaining to business: 1) uncertainty avoidance (willingness to accept risk), 2) tolerance for failure, and a 3) cultures based on individuality versus a collective society. Individuals raised in a culture that has high levels of uncertainty avoidance will experience social resistance to risk. Individuals willing to take persistent risks must have an acceptance of loss; not all efforts succeed, and experience shows that most entrepreneurs fail, sometimes sensationally (Think in terms of Thomas Edison's 10,000 attempts to invent the light bulb), or Steven Spielberg (rejected from 3 film schools), or Henry Ford (founded two automotive companies that failed prior to having success with the Ford Motor Company), and Walt Disney (bankruptcy, mental breakdown, loss of his organization and his cartoon character "Oswald, the Lucky Rabbit") In each of these cases, failure was accepted as valuable learning experience, persistence was necessary. The willingness to face risk and accept failure is heavily influenced by national culture. Some countries (e.g., the United States) have a culture that focuses on success, seeing failure as an obstacle, not an end.

On the other hand, some cultures are not accepting of failure. In Japan, failing a business venture can be fatal to the individual's profession- 
al reputation. In Germany (having a social structure reinforced by rules, laws, and long-term security concerns), failure is seen as a weakness, and inefficiency. Mexico (and many Latin cultures) has little tolerance for failure, considering it a loss of face (social legitimacy.) ${ }^{13}$ Europe is beginning to acquire the cultural acceptance of some failure with regard to business, but has historically viewed business through the cautious lens of potential failure. This can be compared to Silicon Valley's (U.S.A.) often quoted view of "fail often-fail fast." This values experiential learning, improvements and that persistence result in eventual success ${ }^{14,15}$.

Further insight into the influence of culture is seen in the culture measure of social collective versus individualism. This author often reflects on the "Laws of Jante," first appearing in a satirical novel written by Askel Sandemose. The central theme of the laws is the homogeneity of Scandinavian culture. It is comprised of 10 "rules" (an $11^{\text {th }}$ appeared in a subsequently in the novel Penal Code $)^{16}$. The underlying message is one of the importance of the collective, the necessity of conformance, and the disdain for any expression of individuality. This sentiment is not exclusive to the Scandinavian countries. Japan phrase is; “出る釘は打たれる”, which translates into English: "The nail that sticks out gets hammered down." While Japan is not a homogenous culture, there are elements of truth in this saying. Hofstede's cultural dimension of individualism provides insight. ${ }^{17}$ On the individualism / collective scale, the United States is scored at 91 (high individualism), Japan at 46 (high collectivism, low individual orientation), while Poland scores 60 (a little above neutral) ${ }^{17}$.

13 Sue Bryant, "How Different Cultures Deal with Failure," Country Navigator, $5^{\text {th }}$ August, 2019, https://countrynavigator.com/blog/cultural-intelligence/failure-across-cultures/.

14 Glenn, W. Leaper, "Dare to Fail: The Awakening of the European Failure Culture", StartUS Magazine, $10^{\text {th }}$ December, 2015, https://magazine.startus.cc/dare-to-fail-european-failure-culture/.

15 Udechukwu Ojiako, Maxwell Chipulu, Paul Gardiner, Terry Williams, Cultural Imperatives in Perceptions of Project Success and Failure, Project Management Institute 2012.

16 Aksel Sandemose, A Fugitive Crosses His Tracks, translated by Eugene Gay-Tifft. New York: A.A. Knopf., 1936.

17 https://www.hofstede-insights.com/product/compare-countries/. 
There are examples of individuals behaving contrary to cultural constraints and taking risks to seize an opportunity. Consider Ingvar Kamprad, founder of IKEA (1943, Sweden) when he was 17 years old. Consider Fusajiro Yamauchi of Japan, who founded Nintendo in 1889. Consider Kiichiro Toyoda, son of Toyoda Loom Works founder Sakichi Toyoda. Kiichiro assumed the risks to change Toyoda's focus from automatic looms into automobile manufacturing in 1933, creating what became Toyota Motor Corporation. Consider Ross Knap (Poland), initiator of CallPage, a system for real-time analysis of user behavior on websites. Started in 2015, they have over 31 employees $^{18}$ and 3,000 customers as of $2018^{19}$. These examples (there are many) show that while culture helps shape, it cannot completely control entrepreneurial behavior that is reflected in opportunity recognition, or the willingness to take measured risks. It can, however, exert influence on the likelihood of business initiation. The cultural element is therefore seen as a moderating variable (changing the strength of the relationship between the individual and the resulting business origination or development), and can be diagrammed as:

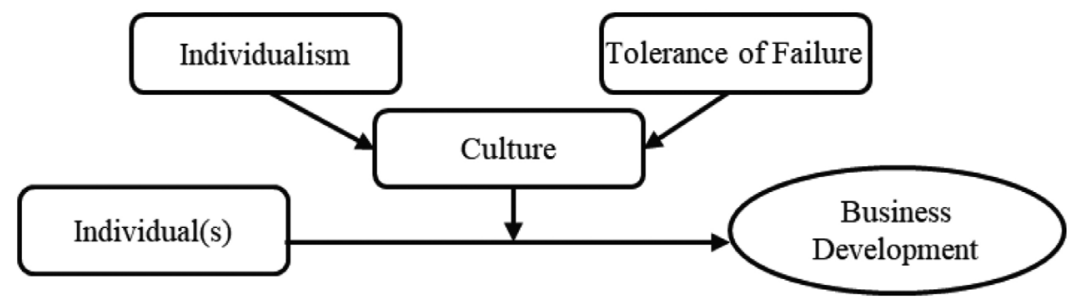

Figure 3: Author's own model diagram

\section{THE GOVERNMENT FACTOR}

Having established the characteristics of the initiating individual and the cultural influences, (essential for the first part of the original ques-

18 https://www.callpage.io/team.

19 https://techcrunch.com/2018/07/31/callpage-lets-you-call-your-website-visitors/. 
tion), we now proceed to exploring the governmental factor. The most comprehensive analysis of global entrepreneurship is maintained by the Global Entrepreneurship and Development Institute. ${ }^{20} 2018$ data shows the United States remains at the highest level (GEI score of 83.6). Poland is ranked $30^{\text {th }}$, with a score of 50.4 , two below Japan, which is ranked at 28, with a GEI score of 51.5. On the other hand, Denmark is ranked $6^{\text {th }}$ (GEI score of 74.3), and Sweden $9^{\text {th }}$, with a GEI score of 73.1. This shows that culture is not the only influence to business activity. Insight is provided by reviewing recent research focusing on the Entrepreneurship Ecosystem which explores the overall environment within which entrepreneurship flourishes ${ }^{21,22,23}$.

One of the key findings of the Entrepreneurship Ecosystem research is that each area of success (ecosystem) is unique, and because of the dynamic interaction of the components, is difficult to imitate. A supportive culture (and other successful ventures) is conducive to inspiration, support from non-governmental institutions is indicated, and infrastructure and the requisite financial and technical support, human capital are evidenced. One of the most counter-intuitive findings has been the necessity of the environment being either free from, or able to overcome cultural biases against failure and business initiatives. The ecosystem will be discussed later.

Governments exist in many forms. The United States is a constitutional republic with democratically selected representatives. It is often stated that if the judgement of the government's programs is delivered at the ballot box (by selecting representatives.) Unfortunately, it is not that simple.

What are the responsibilities of a government? Most persons acknowledge that a government can and should provide goods and services that an

20 https://thegedi.org/global-entrepreneurship-and-development-index/.

21 Daniel Isenberg, "How to Start an Entrepreneurial Revolution," Harvard Business Review 2010, Vol. 88 Issue 6: 40-50

22 Zoltan J. Acs, Saul Estrin, Tomasz Mickiewicz, László Szerb "Entrepreneurship, institutional economics, and economic growth: an ecosystem perspective." Small Business Economics 2018, 51 (2):501-514,DOI: 10.1007/s11187-018-0013-9.

23 Daniel Isenberg, "What an Entrepreneurship Ecosystem Actually Is", Harvard Business Review, 12 ${ }^{\text {th }}$ May, 2014, accessed at https://hbr.org/2014/05/what-an-entrepreneurial-ecosystem-actually-is. 
individual or community is not able to. Consider the following domains and consider to what degree government is responsible, and how its efforts and finances should be prioritized (recognizing that governments operate at different levels and reach):

- Protecting individual freedoms

- Establishing and protecting a system to ensure private property ownership (and transfer)

- Infrastructure (air traffic, highways, bridges, communication across borders)

- Protection from threats and dangers (internal and external)

- Establishing a common financial system to facilitate trade internally and externally

- Managing overall economic conditions

- Establishing and providing healthcare

- Establishing and providing or controlling education

- Redistributing income and resources (wealth redistribution ○ Wealth to poor

o Young to old

o To disabled

○ To socially challenged

o Furnish subsidized housing, food, health care as well as pensions

- Preventing negative externalities

o E.g. pollution, environmental protection, water quality

- Providing psychological or aesthetic protection

o Liquor store or pornographic supply store next to grade school or church

As these issues demonstrate, this becomes a complex choice of the responsibilities and capabilities of the individual and family versus the collective, versus the duly elected government (local, regional and national). Do parents raise their children, does it take a village to raise a child, do government programs direct the maturation of a child?

Governments provide law enforcement personnel, build and maintain highways, and establish a centralized finance system; each of which requires funding. Population growth results in increasing pressures upon governments, resulting in an on-going increase in the size and scope of government. 
The preamble to the U.S. Constitution states that the purpose of the Federal Government is to "establish Justice, ensure domestic tranquility, provide for the common defense, promote the general welfare, and secure the blessings of liberty to ourselves and our posterity"24. Population growth, geographic expansion, and changing technologies and economies increase the scope of the U.S. government's responsibilities. While laws are passed by the elected representatives in Congress, they are implemented through regulations. Regulations are created by a governmental agency, and monitored by political appointees who are not elected by the population. Regulations, however, carry the enforcement mechanisms (effects) of laws. Regulations can be Federal, State, or Local. This impacts business in the following 11 categories, each of which creates an administrative and financial burden on business;

1. Tax codes (Federal, State, Local)

2. Labor laws

3. Employee payment data

4. Collection of taxes (sales, employment, social security, Medicare)

5. Working with independent contractors (persons that are not employees)

6. Insurance

a. The Affordable Care Act of 2010 is approximately 20,000 pages long.

7. Truth / manipulative advertising

a. Electronic marketing

8. State and municipal business licensing

a. Professional qualification licensing

9. Anti-trust laws

10. Environmental regulations

11. Privacy

The most current reports (2018), show the U.S. Federal Register having 78,724 pages in $2006,97,110$ pages in 2016 , and decreasing to 68,082 in 2018. The impact of this is significant and will be discussed further.

24 Preamble to the U.S. Constitution; accessed at https://www.usconstitution.net/ xconst_preamble.html 


\section{THE STATE OF BUSINESS IN THE U.S. "DEMOCRACY"}

As noted, the U.S. is a constitutional republic, within the framework (and control) of a constitution. It is governed under the framework and constraints of constitutional rules of law and the mandates and subject to amendments enacted by democratically elected representatives, and an elected president (elected through a democratic process that selects representatives that become the Electoral College.) This is a form of democracy.

The dynamics and interrelationships of the previously provided models are complex already, but serve to make several facts evident. Culture and governments can constrain entrepreneurial activity, but not stop it. This is evidenced by the emergence of economic activity in the grey (or shadow) economies, as well as criminal enterprise. A few individuals have a sufficiently high level of motivation, competence and risk tolerance that they will pursue any opportunity regardless of risks (including incarceration and death). That, however, is NOT the norm. To be considered a legitimate entrepreneur demonstrating opportunity recognition, the enterprise must be positive to the collective and economically a net contributor. It should be legal, moral, and ethical. Unfortunately, not all executives follow this model.

One of the most significant influences on business feasibility is the expectation of business environment stability. This stability is influenced by the relative stability of the laws and regulations governing business, which are enacted by the government. Imagine considering a business in a country where the political stability is so volatile that there are 5 different presidents within 2 weeks? ${ }^{25}$ Imagine an individual considering a business in Europe in late 1999, when commissioners of the EU resigned en masse. Immediately prior to a major summit, Franz Fischler of Austria walked out of a debate (regarding a report on fraud and mismanagement) declaring "I've resigned. I'm going for a drink!" ${ }^{6}$ This was the beginning of sever-

25 Argentina had five different Presidents in a matter of two weeks in 2001-02. President Fernando de la Rua had resigned from the post on December 20, 2001, after a prolonged economic crisis, and had four successors till January 2, 2002. The last of the five, Eduardo Duhalde remained on the post till May 2003.

26 Martin Walker, "EU Chiefs Resign En Masse," The Guardian, 16 ${ }^{\text {th }}$ March, 1999, accessed at https://www.theguardian.com/world/1999/mar/16/eu.politics1 
al commissioners leaving, which caused a significant change of political power. There are numerous examples of political instability in the world. Arguably, because of changing populace, changing social values and priorities, and a perception of the power of the individual (driven by self-serving benefits), democratic processes are more susceptible to change. Democracy is not the only or most stable system. As stated by D. Alan Heslop, "The simplest definition of a stable political system is one that survives through crises without internal warfare. Several types of political systems have done so, including despotic monarchies, militarist regimes, and other authoritarian and totalitarian systems" 27 .

Within the U.S.'s form of democracy, changes are less sudden, as illustrated by the economic changes that can be attributed to various political factors, ranging from financial stimulus to restrictive regulations and trade theories. To understand why the governmental effects are so pronounced on business, it is helpful to explore the concept of entrepreneurship ecosystems. While many of the foundations of this theoretical framework can be traced to the late $19^{\text {th }}$ and early $20^{\text {th }}$ century, scholars generally agree that the basics were solidified in the late $20^{\text {th }}$ century as an outgrowth of the concept of the Triple Helix which considered the relationships of government, industry, and universities (a foundation of industrial economics). The ecosystem phrase and model were proposed by Daniel Isenberg in the Harvard Business Review in 2010, further clarified in 2011 and $2014^{28,29,30 .}$

27 D. Alan Heslop, (undated) "Stable Political Systems," at https://www.britannica. $\mathrm{com} /$ topic/political-system/Stable-political-systems (the author encourages readers to read Heslop's paper in its entirety).

28 Daniel Isenberg, "How to Start an Entrepreneurial Revolution," Harvard Business Review 2010, June 10, Vol. 88 Issue 6, p40-50.

29 Daniel Isenberg, "Introducing the Entrepreneurship Ecosystem: Four Defining Characteristics," Forbes.com, May 25, accessed at https:/www.forbes.com/sites/danisenberg/2011/05/25/introducing-the-entrepreneurship-ecosystem-four-defining-characteristics/\#2319a8b55fe8.

30 Daniel Isenberg, What an Entrepreneurial Ecosystem Actually is," Harvard Business Review On-Line, May 12 2014, accessed at https://hbr.org/2014/05/what-an-entrepreneurial-ecosystem-actually-is. 
While scholars approach the entrepreneurship ecosystem in different ways, the concept (as established by Isenberg) has four defining assumptions (characteristics):

1. There are six domains (categories), each consisting of hundreds of individual elements.

- A conducive culture

- Policy and leadership

- Appropriate finance

- Quality human capital

- Venture friendly markets

- Infrastructural support(s)

2. Each entrepreneurship ecosystem is unique, and inimitable.

3. Attempting to specify the underlying causes of successful ecosystem has limited the practical value. This manifests the complexity of the ecosystem, and the result of high-order interaction made possible by unique individuals and circumstances.

4. Entrepreneurship ecosystems become relatively self-sustaining; success breeds further success in enhancing the six domains.

In the original conceptual diagram of the Entrepreneurship Ecosystem, the entrepreneur (individual(s)) is shown in the center of the surrounding domains. As stated previously, the individual requires characteristics of risk tolerance, opportunity recognition, as well as technical and personal competencies (pg 7-8). Culture has multiple dimensions ( $p g$ 8-11; the social dimension, include social norms, tolerance of failure, mentors and examples of success, etc.), human capital, (educational institutions as well as breadth and depth of skilled and unskilled labor), and markets (customers, distribution channels, networks). The influence of government is evidenced in three domains: policy (government, leadership, and venture-friendly legislation), supports (infrastructure, support professionals), and finance (loans, investors, availability and cost of financing).

We demonstrate some of the interaction by looking at the past 20 years of business and entrepreneurship in the U.S. In addition to the ordinary volatility experienced by businesses, there are visible trends - which can be seen to decrease business initiation as well as job creation (charts 1 and 2 in Appendixes). Further insight is provided into administrative perspectives on business. Larger, established businesses or smaller businesses may ben- 
efit at different times, correlated to changing administrations. (Chart 3) in appendix ${ }^{31}$.

It is helpful to note that less than somewhere between $8 \%$ (as cited by Southerland) to "more than $20 \%$ (as cited by Cembalest in the same article) of the Obama administration (including cabinet and political appoints) had significant private sector job experience (not counting lawyers), while both President Eisenhower and President Reagan had administrations with close to $60 \%{ }^{32}$. Five of the 15 persons President Trump nominated to the Cabinet have spent all or nearly all of their careers in Business (with no significant public office or senior military service). Final numbers for administration are lacking because many of the appointees are pending.

The Pew Research Center offers graphs on the different attitudes regarding government administrator's private sector experience over the past 100 years. Four presidents stand out as pro-business (McKinley, Eisenhower, Reagan, and Trump) ${ }^{33}$. It is apparent that differing perspectives on the role of private enterprise within a country's strategic objectives impact business and economic consequences. In addition to the graphs (showing the changes in business formation, job creation, and impact of small business versus large businesses as economic contributors), overall economic activity is gathered from the Hudson Institute and Statista. ${ }^{34}$ Under President Clinton's administration (1993-2000), the average annual change in of GDP per capita was 3.8\%. Businesses were formed and jobs created at a nominal $4 \%$ increasing rate and smaller business carried a large share of the economy. Under President G.W. Bush's administration (2001-2009), the economy declined $1.1 \%$ (change in GDP average over eight years). Larger businesses were favored and expanded (greater share of employ-

31 https://www.bls.gov/bdm/entrepreneurship/entrepreneurship.htm

32 Steve Southerland, "Comments at the Liberty County Chamber of Commerce Annual Dinner", appearing in Politifact.com, accessed at: https://www.politifact.com/ factchecks/2011/jan/20/steve-southerland/92-percent-obama-administration-has-no-private-sec/

33 https://www.pewresearch.org/fact-tank/2017/01/19/trumps-cabinet-will-be-oneof-most-business-heavy-in-u-s-history/.

34 https://www.hudson.org/research/12714-economic-growth-by-president and https:// www.statista.com/statistics/238600/gdp-per-capita-growth-by-us-president-from-hoover-toobama/. 
ment) and new business formation declined. Under President Obama's administration (2009-2016) overall economic decline continued in spite of higher numbers in new business formation. With continuing effects of the financial crisis and recession of 2007-2008, jobs were lost due to cut backs and layoffs. This often results in persons becoming self-employed (when jobs are not available (called push motivation) ${ }^{35}$. With these influences and with an increase in government size and regulatory control, the GDP annual change fell by $-.42 \%$. Business formation and labor utilization can be seen to have declined, and large businesses share of the economy grew. President Trump demonstrates a different direction. Since the 2016 election, real growth has been $2.6 \%$, considerably higher than the G7 average (excluding the U.S.) which measures $1.5 . \%$. (since the term in office has not been completed, average net change in GDP is not available)

As noted, there has been a significant reduction in federal regulations impacting business, in addition to changes in the income tax structure and rates. President Trump, in the first month of his presidency, issued an executive order to reduce government spending and regulations ${ }^{36}$. Underlying the previously mentioned significant reduction in the length of the Federal Register is the reduction in "economically significant" Rules impacting businesses; a 27\% decrease in the first year of his term. All of this shows a more positive direction of the governmental dimension in the entrepreneurship ecosystem of the U.S.

\section{CONCLUSION}

As demonstrated by the economic health and standing of the United States versus the G7 average, business is in comparatively good health within the representative democratic constitutional republic of the United States - a truly unique form of democracy. At the same time, business con-

35 Emeric Solymossy, "Push / Pull Motivation: Does it Matter in Terms of Venture Performance?", in Frontiers in Entrepreneurship Research, edited by P.D. Reynolds, W.D. Bygrave, N.M. Carter, P. Davidsson, C.M.Mason, and P.P. McDougall, Babson College, Boston, MA, 1997, 204-217.

36 https://www.whitehouse.gov/presidential-actions/presidential-executive-order-reducing-regulation-controlling-regulatory-costs/. 
fidence fluctuates drastically not only by changing administrations, but to a greater degree within each 4 years period of each administrative period ${ }^{37}$.

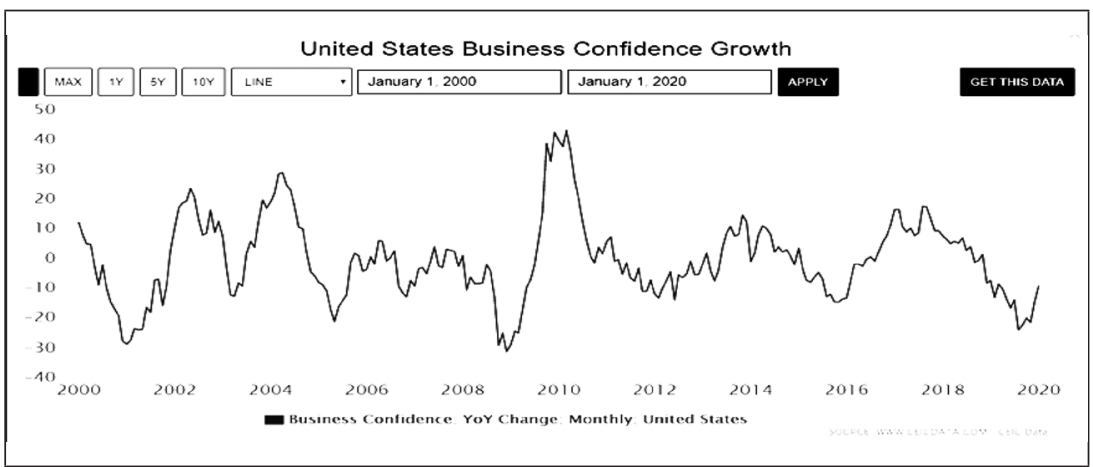

Figure 4: Data accessed and graphed at https://www.ceicdata.com/en/indicator/ united-states/business-confidence-growth

Business confidence is affected by many things; consumer sentiment, labor availability, financial costs and availability, perceived inflation, and global issues Thoughtful analysis argues that the complex dynamic of motivated, competent and risk-willing individuals operating within a culture that provides a depth of experience and support and accepts failure are not by themselves sufficient. The presence of a self-sustaining ecosystem cannot be underestimated. The attitudes of government as well as external factors can constrict business, repress business formation, employment, and economic growth, or it can facilitate innovation and provide business incubators and tax incentives for business success. It is this author's conviction that the form of government is not as critical as the government's attitude towards the business environment (promote and facilitate, or suppress and control) in driving business health and economic prosperity.

37 https://www.ceicdata.com/en/indicator/united-states/business-confidence-growth. 


\section{REFERENCES}

Acs, Zoltan J., Saul Estrin, Tomasz Mickiewicz, and László Szerb. "Entrepreneurship, Institutional Economics, And Economic Growth: An Ecosystem Perspective” Small Business Economics, V51-2 2018.

Berry, Tim. (undated) "35 Common Characteristic of Successful Entrepreneurs," Bplans, on Palo Alto Software, at https://articles.bplans.com/35-common-characteristics-of-successful-entrepreneurs/.

Bohn, H. G. The Standard Library Cyclopedia of Political, Constitutional, Statistical and Forensic Knowledge. 4 volumes, Covent Garden, N.Y. p. 640, 1849.

Bryant, Sue. "How Different Cultures Deal with Failure". Country Navigator 2019, https://countrynavigator.com/blog/cultural-intelligence/failure-across-cultures/.

Chipulu, Maxwell, Udechukwu Ojiako, Paul Gardiner, Terry Williams, Vital Anantatmula, Caroline Mota, Stuart Maguire, Yongyi Shou, Peter Nwilo, and Vachara Peansupap. Cultural Imperatives in Perceptions of Project Success and Failure, Project Management Institute, 2012.

De Soto, Hernando. The Mystery of Capital: Why Capitalism Triumphs in the West and Fails Everywhere Else, (Basic Books, 2000).

Friedman, George. "The Founding Fathers Never Intended to Create A Direct Democracy”. Huffington Post 2017 at: https://www.huffpost.com/entry/thefounding-fathers-never-meant-to-create_b_13051196.

Helsop, D. Alan. (undated) "Stable Political Systems," at https://www.britannica. $\mathrm{com} /$ topic/political-system/Stable-political-systems.

Holcombe, Randall. Liberty in Peril, 2019.

Isenberg, Daniel. "How to Start an Entrepreneurial Revolution”. Harvard Business Review 2010.

Isenberg, Daniel. "Introducing the Entrepreneurship Ecosystem: Four Defining Characteristics". Forbes.com, 2011 May 25, accessed at https://www.forbes. $\mathrm{com} /$ sites/danisenberg/2011/05/25/introducing-the-entrepreneurship ecosystem-four-defining-characteristics/\#2319a8b55fe8.

Isenberg, Daniel. "What an Entrepreneurship Ecosystem Actually Is". Harvard Business Review 2014 May 12. accessed at https://hbr.org/2014/05/ what-an-entrepreneurial-ecosystem-actually-is.

Leaper, Glenn, W. "Dare to Fail: The Awakening of the European Failure Culture". Start US Magazine. 2015. at https://magazine.startus.cc/dare-to-fail-european-failure-culture/.

Roser, Max. "Which countries achieved economic growth? And why does it matter?” from Our World in Data 2019, at https://ourworldindata.org/economic-growth-since-1950. 
Rosseau, Jean-Jacques. On the Social Contract; or, Principles of Political Rights, Published by Marc Michel, Rev., Amsterdam 1762.

Sandemose, Aksel. A Fugitive Crosses His Tracks, translated by Eugene Gay-Tifft. New York: A.A. Knopf 1936.

Thompson, Dennis. John Stuart Mill and Representative Government. Princeton University Press, 1976.

Solymossy, Emeric. "Push / Pull Motivation: Does it Matter in Terms of Venture Performance?” pp. 204-217, In Frontiers in Entrepreneurship Research, edited by P.D. Reynolds, W.D. Bygrave, N.M. Carter, P. Davidsson, C.M.Mason, and P.P. McDougall, Babson College, Boston, MA 1997.

Southerland, Steve. Comments at the Liberty County Chamber of Commerce Annual Dinner, appearing in Politifact.com 2011, appearing in https://www.politifact.com/florida/statements/2011/jan/20/steve-southerland/92-percent-obama-administration-has-no-private-sec/.

Figure 1; Three Charts from the Bureau of Labor Statistics, https://www.bls.gov/ $\mathrm{bdm} /$ entrepreneurship/entrepreneurship.htm. 


\section{APPENDIX}

Figure 1; Three Charts from the Bureau of Labor Statistics
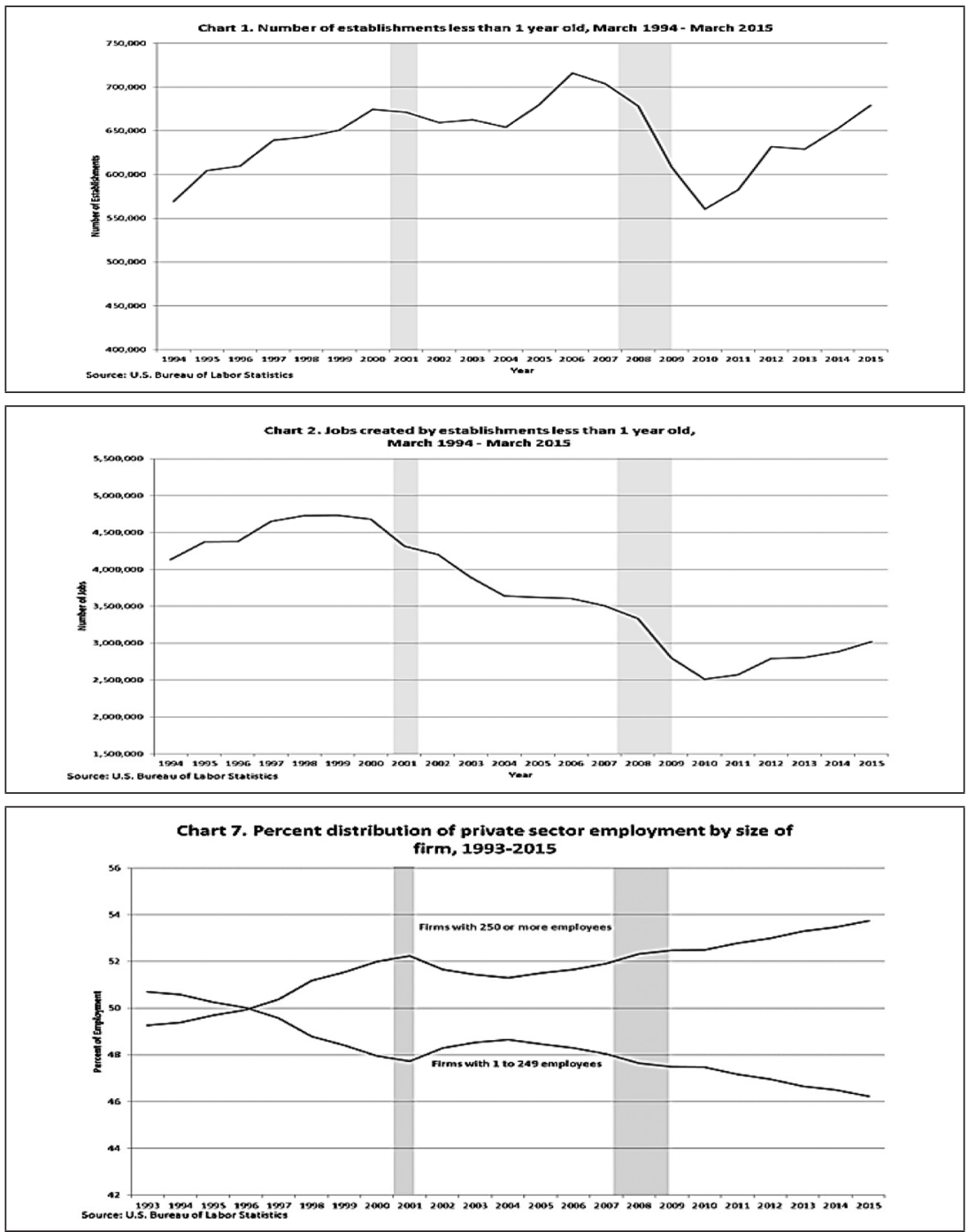

https://www.bls.gov/bdm/entrepreneurshiplentrepreneurship.htm 
